\title{
Comparative Analysis of Conventional Mortars and Instant Mortars (RAPI) Against Stone and Plastering Wall Pairs Judging from Quality, Cost, and Time
}

\author{
Hamonangan, GIRSANG, \\ Faculty of Engineering, Mercu Buana University, Indonesia, \\ hamongirsang@gmail.com \\ TB. Muhammad Nazmi , HABIBI, \\ Faculty of Engineering, Mercu Buana University, Indonesia, \\ Habibi0192@gmail.com@gmail.com
}

\begin{abstract}
The development of technology in construction has resulted in ready-made Mortar products is one product that is increasingly needed in the construction industry for several reasons such as material source, project location, quality accuracy, material efficiency, management and price factors. The larger the scale of the city and the more difficult to get quality materials at low prices and increasingly complex handling, it is enough to make an excuse in developing a more practical product with better quality assurance. The aim is to lead to ease in the process of work in the field while continuing to prioritize quality, but its utilization is still not maximized. This study tries to determine the neat instant mortar comparison with conventional mortar against the cost, quality, and time of the red brick and plastering wall pairs. The results showed that the compressive strength in 28 days the compressive strength of Mortar RM-115 with a compressive strength of $215.88 \mathrm{~kg} / \mathrm{cm} 2$ which is larger and more measurable than Conventional Mortar with a value of $151.76 \mathrm{~kg} / \mathrm{cm} 2$ whose implementation is sometimes incorrect. The time needed to complete the red brick wall pair work using Mortar RM-115 material is 14 days, while the time needed on the work of the red brick wall pair Conventional Mortar material is 15 days. So that the work of the red brick wall pair using the Mortar RM-115 material is more efficient 1 day and cleaner storage compared to using conventional Mortar material. The price of installing red brick walls with Mortar RM-115 materials in Bintaro Sector 7 housing is Rp. 36,858,425.99. While the price of installing red brick walls and plastering using conventional Mortar materials in Bintaro Sector 7 housing is Rp. 47,188,780.22. Work Installation of red brick walls and plaster using Mortar materials RM115 is more expensive with a difference of Rp. 10,330,354.23.
\end{abstract}

Keywords: Comparative Analysis of Conventional Mortar and Instant Mortar (RAPI) Against a Pair of Bricks and Plastering Walls Judging From Quality, Biaya, and Time.

\section{INTRODUCTION}

Current technological developments have led to the era of globalization by emphasizing product quality and efficiency. Problems that are often encountered in the field and demands must be answered by developing innovations to produce a product that is more competitive, applicable and easy to apply in the field. Mortar as a binding material in the work of couples and plastering and other settlement work plays an important role because in addition to meeting technical requirements, it must also provide high decorative value. The function of mortar in wall pairs is as a binder between brick elements, eliminating the brick surface deviation, and channeling the load received by the wall components. While the function of mortar in plaster is leveling the surface, beautifying the building, preventing wasteful use of paint and protecting from the influence of weather.

With the increase in construction activities, especially buildings and housing needs to be balanced with the availability of adequate materials. The problems faced today are the increasingly limited sources of raw materials, the difficulty of transportation, limited land, the amount of material wasted, and the demands of product quality, especially in big cities. Therefore it is necessary to look for alternative solutions that are better in 
addressing the problem as an effort to develop technology while fulfilling quality assurance in line with global demands.

In this study not only aims to inform about the choice of wall materials but also the comparison of advantages and disadvantages including material properties, costs and implementation time between conventional and new materials.

The development of technology in construction has resulted in ready-made Mortar products is one product that is increasingly needed in the construction industry for several reasons such as material source, project location, quality accuracy, material efficiency, management and price factors. The larger the scale of the city and the more difficult to get quality materials at low prices and increasingly complex handling, it is enough to make an excuse in developing a more practical product with better quality assurance. Mortar Ready to Use (MSP) currently in use from PT. Rapi Hijau Perkasa PT. Duta Sarana Perkasa with RAPI Mortar Brand products that are used for various jobs such as residential buildings (towers and apartments), office buildings, education, industry, hotels, malls and others, where demands for quality and work efficiency are needed. Furthermore, if the current mortar product has developed sufficiently to meet the technical requirements and in accordance with the intended use, it needs further study and research so that it can answer the problem.

Of course, knowledge about this is needed, considering the addition of mortar strength is also associated with additional costs. Therefore it is necessary to conduct further research on the compressive strength of the couple walls against more variations in the composition of the mortar mixture, and the optimization of the use of mortar on the red brick pair walls. As the author is interested in taking the title of a comparative analysis of neat mortar with conventional mortar against the installation of brick and stucco walls in terms of quality, cost, and time.

The wall is a part of the building that functions as a weight bearing, giving weight throughout the building, as a silencer and radiation, separating the outside space from the inside, protecting against the weather, roofing, as a barrier, and retaining heat from the sun, and withstand wind the wind outside. The wall is a very important part of the building's role for a building construction. The walls form and protect the contents of the building both in terms of construction and artistic appearance of the building. (Fianli, 2011).

\section{Batu Bata}

Brick or red brick is an artificial stone made from clay or clay, dried in the sun for several days depending on weather conditions, then deposited, so that the course of the combustion fire can be evenly distributed to the outer pile layer.

The strength of a brick is greatly influenced by the composition of the raw materials making up the combustion temperature, the manufacturing process, and its porosity. Ideal brick size:

$$
\begin{aligned}
& \text { Length }=23-24 \mathrm{~cm} \\
& \text { Width }=11-11.5 \mathrm{~cm} \\
& \text { Thickness }=5-6 \mathrm{~cm}
\end{aligned}
$$

With each allowable deviation for the size is a maximum length of $3 \%$, a maximum width of $4 \%$ and a maximum thickness of $5 \%$. (Frick, 1980). 


\section{Mortar}

Mortar or species, or mortar, according to Murdock, R. (1980) is a mixture composed of cement, sand, water, in a certain time will harden like rocks. In construction work, Mortar is used as a binding material for bricks, stones and concrete blocks. Mortar can function as a structural construction as well as non-structural construction. In the structural construction Mortar is used as a wall species and foundation, while for non-structural mortar construction is used as an outer wall coating. As a structural construction, Mortar is planned to withstand the compressive force (as a binder on a brick wall or foundation) as well as the glue between red bricks in making walls inside the house or outside the house, stone adhesive in foundation construction, or as a layer of plaster on brick wall surface, or the other. For this reason, it is necessary to know the compressive strength that can be held by the mortar both during the construction process and after construction is planned to be able to withstand all loads. Mortar ingredients can also be added to add ingredients to accelerate hardening or other purposes (Tjokrodimuljo, 1996).

Mortar strength is needed to deal with the forces on the wall or the work of couples who work in a direction parallel to the fiber pressing the mortar and has a minimum compressive strength equal to the compressive strength on the red brick.

According to SNI 03-6882-2002; 2-3 and ASTM C 270, mortar is classified into 4 types based on proportion of ingredients and property specifications, namely: $\mathrm{M}, \mathrm{S}, \mathrm{N}$, and $\mathrm{O}$, each type consists of fine aggregate (sand), water and cement.

Wall pairs receive compressive loads caused by influences from above, wind, or other side forces. In ASTM C 270 mortar classification based on compressive strength and designation are given in the table below.

Tabel 1. Mortar properties specification requirements

\begin{tabular}{cccccc}
\hline Mortar & Type & $\begin{array}{c}\text { Strength on } \\
\text { average 28 } \\
\text { days min. } \\
(\mathrm{MPa})\end{array}$ & $\begin{array}{c}\text { Retention } \\
\text { Water } \\
\text { Min }(\%)\end{array}$ & $\begin{array}{c}\text { Until } \\
\text { udara max } \\
(\%)\end{array}$ & $\begin{array}{c}\text { Aggregate ratio } \\
\text { (measurement of } \\
\text { damp and loose } \\
\text { conditions) }\end{array}$ \\
\hline Cement & $\mathrm{M}$ & 17,2 & 75 & $\ldots . \mathrm{b})$ & $2,25-3$ times \\
couple & $\mathrm{N}$ & 12,4 & 75 & $\ldots \ldots \mathrm{b})$ & the amount \\
& $\mathrm{O}$ & 5,2 & 75 & $\ldots . \mathrm{b})$ & volume is \\
cement
\end{tabular}

(Sumber:SNI 03-6882, 2002: 3)

Tabel 2. Klasifikasi Kuat Tekan Mortar \& Penggunaannya

\begin{tabular}{ccc}
\hline Stir Type & Power & Recommendations for Use \\
\hline Type M & $\begin{array}{c}\text { The minimum } \\
\text { strength } \\
\text { compressive strength is } \\
175 \mathrm{~kg} / \mathrm{cm}^{2} .\end{array}$ \\
Type N & $\begin{array}{c}\text { Press firmly on medium } \\
\text { Minimum pressure of } 124 \\
\mathrm{~kg} / \mathrm{cm}^{2} .\end{array}$ \\
$\begin{array}{c}\text { Mix well with medium } \\
\text { press }\end{array}$ & $\begin{array}{c}\text { For reinforced brick walls, walls } \\
\text { near the ground, foundation pairs, } \\
\text { mix dirty water pipe pairs, mix } \\
\text { retaining walls and mix for roads } \\
\text { Used without the use of type } \mathrm{M}, \\
\text { but high tensile strength and side } \\
\text { force. }\end{array}$ \\
$\begin{array}{c}\text { Pressure at minimum } 52,5 \\
\mathrm{~kg} / \mathrm{cm}^{2} .\end{array}$ & $\begin{array}{c}\text { Used for open couples on the } \\
\text { ground. }\end{array}$ \\
\hline
\end{tabular}




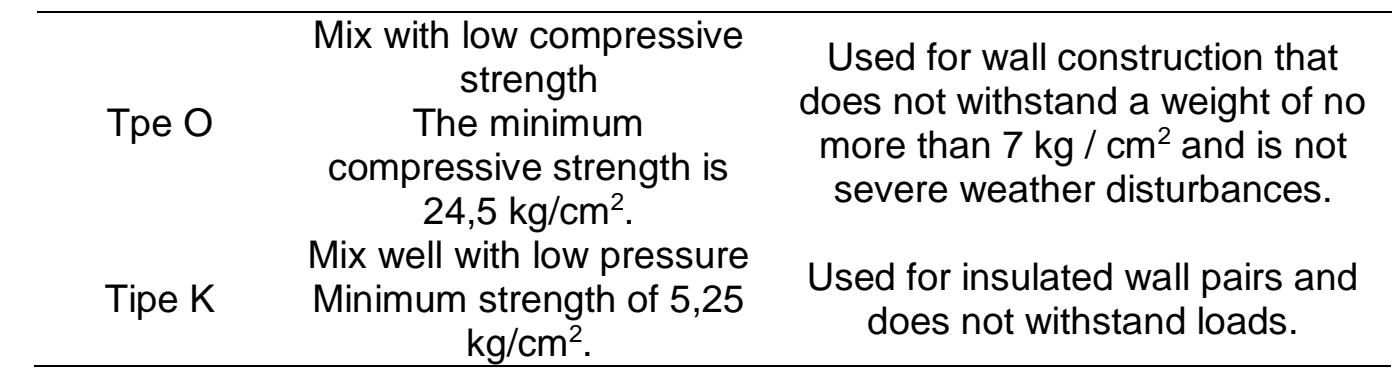

(Sumber : ASTM C270)

For brick wall installation, mortar used is generally mortar that is manually processed or called conventional mortar. Mortar types formed conventionally have not been able to meet all the needs of the field and the desired requirements so that modifications and innovations must be made both in terms of material aspects, the proportion of mixed engineering implementation and so on. Kinds of mortar mortar test are: the crash test, testing of mortar that has been hard, namely the compressive test, tensile strength and adhesion (Tjokrodimuljo, 2007; 79-84).

Based on SNI 2837-2008, both mixtures and material requirements are used for plastering in accordance with technical specifications and according to requirements, namely $1: 3,1: 4$, and $1: 5$. This is the basis for making mortar in this study using a new type of mixing material with better technical properties is an indication of the success of the technology that can be applied as an effort to improve construction quality and cost efficiency. Increasingly complex demands for needs also need to be responded to wisely and make expectations and opportunities in business development. Mortar ready to use (Instant Mortar) is one of the products that are increasingly needed in the construction industry for several reasons such as material source, project location, product quality, management and price factors. The increasing scale of the city and the difficulty of getting quality materials at low prices and increasingly complex handling would be enough to make an excuse in developing a more practical product with better quality assurance. (Lasino, L., \& Rachman, D. (2012)).

Mortar ready to use (Instant Mortar is a mixture of cement, silica sand, additives) and several other materials that can be mixed into one. Cement mortar is highly recommended for the needs of the construction of residential homes, because it has many advantages that are produced in factories so that the quality and quantity can be trusted when compared to manufacturing in the field, easy, just add water, the existence of adding additives to the mortar can overcome the occurrence of the floor lifted, cracked / cracked walls, etc. Some instant mortar products that have been issued by PT. Green Mighty Rapi which has been widely found in the market that is Rapi Mortar is one brand of instant mortar products whose products are quite complete. One of the products we will test for the compressive strength of masonry walls is the neat Instant Neat RM-115 function for the installation of brick and plaster walls.

\section{Construction Materials for Red Brick Walls}

\section{a. Semen}

Semen Portland didefinisikan sebagai semen hidrolis yang dihasilkan dengan cara menggiling terak semen portland terutama yang terdiri atas kalsium silikat yang bersifat hidrolis dan digiling bersama-sama dengan bahan tambahan berupa satu atau lebih bentuk Kristal senyawa kalsium sulfat dan boleh ditambah dengan bahan tambahan lain (SNI 15-2049-2004).

b. Sand 
According to the Decree of SNI T-15-1990-03, sand roughness is divided into 4 (four) zone gradation groups adopted from the British Standard used in Indonesia today, namely: fine sand, rather fine, rather rough. These four gradations are usually referred to as zone I (coarse sand), zone II (coarse sand), zone III (coarse sand) and zone IV (fine sand).

\section{c. Water}

In general it is known that the higher the value of the cement water factor (FAS), the lower the strength quality of concrete. However, a lower FAS value does not always mean that the strength of the concrete is higher. A lower FAS value causes difficulties in the workmanship, namely difficulties in carrying out compaction which will ultimately cause the concrete quality to decrease. Generally the value of FAS is given between 0.4 - 0.65 (Mulyono, 2004).

\section{d. Additives (addictive)}

Additives such as coloring agents, forming agents, air bubbles, accelerating or slowing down the reaction, water repellent, and other additives should not be added to the mortar unless specified conditions. If in the contract document the calcium chloride compound is clearly stated, it can be used as a hardening accelerator with a maximum amount of $2 \%$ calculated on the weight of Portland Semem grade or $1 \%$ on the weight of paired cement or a percentage of both in the mortar concerned. If it is permissible to use calcium chloride, its use must be carried out with caution, because these compounds can damage metals and some of the wall covering material. General, D. P. (2002).

\section{Kuat Tekan Mortar}

Mortar compressive strength is often used as a basic criterion for the distribution of mortar types, because measuring compressive strength of mortars is easier and can usually be directly connected to other mortar capabilities such as tensile strength and absorption capacity of mortars (ASTM C 270). Mortar compressive strength is carried out by mortar specimens with dimensions of $5 \times 5 \times 5$ em as many as 5 test specimens.

According to SNI 03-6825-2002, in the test of compressive strength of mortar the test object is cuboid in the size of $5 \mathrm{~cm}$. The compressive strength value is obtained by dividing the maximum load weight $(\mathrm{N})$ by the viewing area $\left(\mathrm{mm}^{2}\right)$. The equation used in determining the compressive strength value of mortar $(\sigma)$ can be

seen in Equation 3.

$\sigma=(P \max ) / A \ldots \ldots \ldots(2)$

Where, Pmax, maximum compressive force, and A, cross-sectional area.

Mortar testing was carried out using cube-shaped mortar with $50 \mathrm{~mm}$ with a ratio of 1:4 cement and sand mixture and Instant Neat Mortar. Testing the compressive strength of mortar can be seen in Figure 2.3.

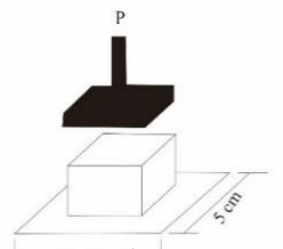

Figure 1. Mortar Compressive Strength Test

(Source : ASTM C 270) 


\section{RESEARCH METHODOLOGY}

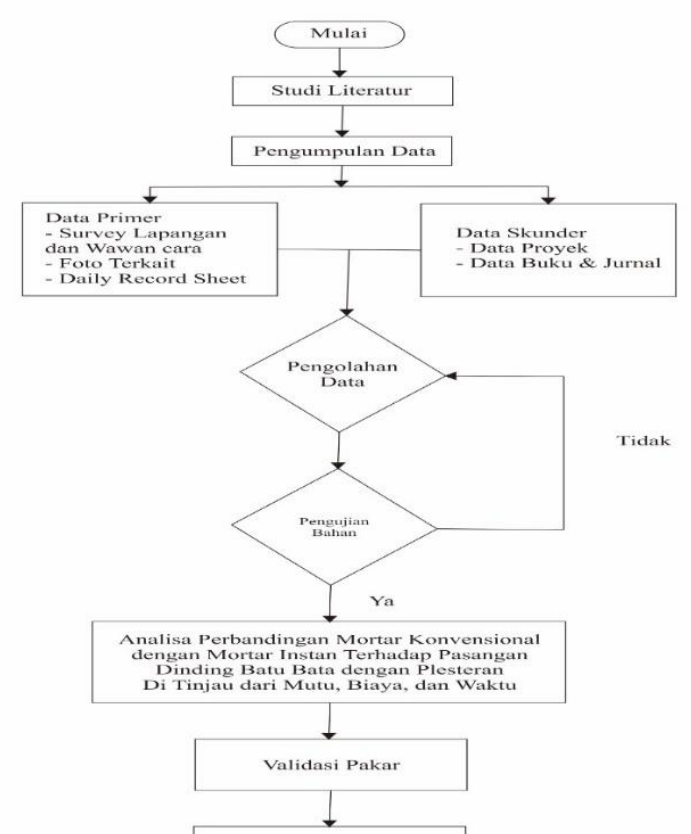

Figure 2mResearch Flow Chart

(Source $\downarrow$ Author, 2019)

The method used in this research is dafâle retrieval with the testing process carried out in the laboratory. The purpose of this stage is to obtain data carried out at the research method stage. The data used in this study are primary data and secondary data, including :

a Primary Data

- Field surveys and interviews.

- Photos related to the tool used for testing.

- Daily record sheet

b Secondary Data

- Project data

- Books and journals

\section{Data Processing}

After all the data needed in the research has been obtained, the next step is to make the modeling that the author wants. The manufacture of test specimens will be carried out in the laboratory.

Research variable

a) The independent variable (independent variable), the variable whose changes are free is determined by the researcher. In this study the independent variable is the composition of the conventional Mortar mixture used 1:1:5 which will be compared with the Neat Instant Mortar production from PT. Ambassador of Mighty Facilities.

b) Dependent variable (dependent variable), the variable whose change depends on changes in the independent variable. In this research, the dependent variable is the compressive strength of mortar.

\section{Material Testing}




\section{a. Test Press Test Objects}

Namely testing the strength of Neat Instant Mortar on the brick wall pair material, and Conventional Mortar compressive strength of red brick obtained from the laboratory of PT. Ambassador Sarana Perkasa which will be carried out by researchers. Mortar compressive strength test Mortar specimens made with dimensions of $5 \times 5 \times 5$ em $(+1.5$ $\mathrm{mm}-3 \mathrm{~mm}$ ) of at least 3 pieces, with an aggregate of 1.6 to $10 \mathrm{~mm}$, Align the compressed objects and the stand before testing, Tests carried out at $3,7,28$ days, and If there is an average difference of greater than $15 \%$, the test must be repeated.

\section{RESULTS AND DISCUSSION}

\section{Material Testing}

1) The working steps of making mortar

a. Mortar Composition

- To determine the composition of the instant RM-115 neat mortar in this study using a volume ratio of $1: 5$ using a $200 \mathrm{ml}$ measuring cup, to make 9 samples needed, namely:

1) Prepare $2.09 \mathrm{~kg}$ of instant mortar.

2) Prepare $417.15 \mathrm{ml}$ of water.

3) Mix evenly the mortar mixture in the container using a mixer.

4) Stir the mortar for 420 seconds

5) Mortar is ready to be printed, pour into the cube $50 \mathrm{~cm} \times 50 \mathrm{~mm} \times 50 \mathrm{~mm}$ until it is evenly distributed.

- As for the conventional mortar composition in this study using a ratio of $1: 5$ volume to make 9 samples needed, namely:

1) Prepare $0.55 \mathrm{~kg}$ of holcim cement

2) Prepare $2.35 \mathrm{~kg}$ of white sand

3) Prepare $209.25 \mathrm{ml}$ of water

4) Mix evenly the mortar mixture in the container using a mixer.

5) Stir the mortar for 420 seconds

6) Mortar is ready to be printed, pour into the cube $50 \mathrm{~cm} \times 50 \mathrm{~mm} \times 50 \mathrm{~mm}$ until it is evenly distributed.

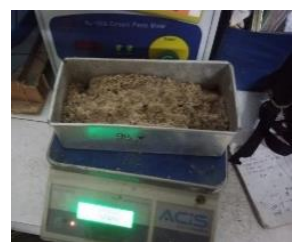

Figure 4.1 The material is weighed first to adjust the composition

(Source: Author, 2020)

b. Mortar Print

After the mortar mixture is ready, the next step is to print the mortar with a $50 \times 50 \times 50$ mm mortar mold.

1) Prepare the mortar that is ready to be printed.

2) Put the mortar into the mold until it is flat on the surface.

3) Let stand for $1 \times 24$ hours until the mortar mixture dries.

4) When the mortar has dried, give a date (according to the date of manufacture).




Figure 3. Mortar Enter into the mold

(Source: Author, 2020)

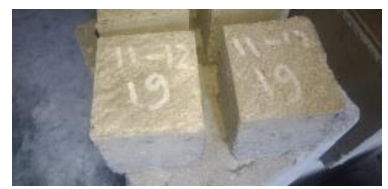

Figure 4. Mortar given date of manufacture

b. Mortar Immersion Process

(Source: Author, 2020)

1) Put all the test items into the soaking tub.

2) At this stage the test specimen is treated (curing), by immersion in water. Wait until the age of the test object matches the test, (the age of the test being tested is 3 days, 7 days and 28 days).

1) The test work step

a. Drying and weighing processes

1) Lift the test object (age 3 days) from the soaking tub, wait until it is completely dry.

2) Then weigh the test specimen..

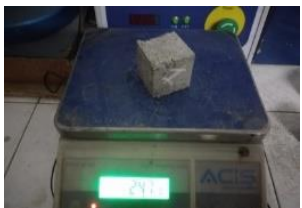

Figure 5. Weigh after soaking the age of 3 days

(Source: Author, 2020)

a. Compressive strength testing

1) After making and maintaining the test specimen, the compressive strength test is then performed.

2) Compressive strength testing is done after the specimen reaches the age of 3 days, 7 days and 28 days from the time of mixing.

3) For each age 3 specimens are made, so in total there are 9 specimens which will be tested for compressive strength.

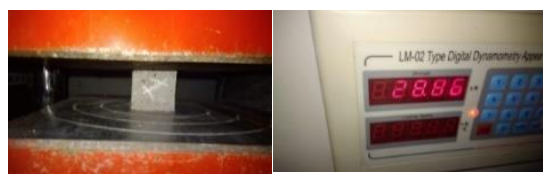

Figure 6. The compressive strength testing process

(Source: Author, 2020))

Table 3. Test Results of Mortar Compressive Strength Day 3, 7, 28

\begin{tabular}{ccccc}
\hline & & \multicolumn{3}{c}{ Compressive Strength $(\mathrm{kg} /$} \\
No & Matrial Mortar Material & \multicolumn{3}{c}{$\left.\mathrm{cm}^{2}\right)$} \\
& & $3 \mathrm{hr}$ & $7 \mathrm{hr}$ & $28 \mathrm{hr}$ \\
1 & Conventional & 118,18 & 116,49 & 151,76 \\
2 & RM-115 & 100,96 & 105,4 & 215,88 \\
\hline
\end{tabular}

(Sumber : Penulis, 2020)

\section{Work productivity}

a. Measurement of Work Productivity

During the work, the amount of achievement must be recorded so that it can be compared with the initial plan as an effort to evaluate the amount of productivity that has 
been achieved. Monitoring (monitoring) means conducting observations and testing at each specific interval to check the performance and unexpected side effects (Istimawan, 1996: 423 in Mohamad Harun's research).

In general, productivity can be interpreted as a comparison between output and input. Productivity is expressed by Formulas (Thomas, 1999 in Sentosa Limanto's research, 2011)..

$$
\text { Productivity }=\frac{\text { Output }}{\text { Input }}
$$

As for the measurement of worker productivity, what is used is :

$$
\text { Worker Productivity }\left(\mathrm{m}^{2} / \mathrm{jam}\right)=\frac{\text { Work Results }\left(\mathrm{m}^{2}\right)}{\text { Hours } / \text { Duration of work }}
$$

b. Productivity Measurement Method

The method used in measuring the productivity of wall mounting is the Baseline Productivity method and from the field work report or Daily record sheet.

\section{c. Baseline Productivity}

Standard productivity values can occur when there is no or only minimal disturbance in the field. This productivity value is the baseline productivity. The productivity baseline shows the standard productivity values targeted by the contractor in part of a project (Thomas, 2000). Baseline productivity is an optimal productivity condition that can be achieved.

\section{d. Daily Record Sheet}

Daily record sheet is daily productivity. The volume of work produced on that day divided by work time is formulated as follows :

\section{Observation Result of Stone Wall Installation}

$$
\text { Dily Productivity }=\frac{\text { Daily Quantity }}{\text { Daily Work Hours }} \times 8 \text { hour }
$$

- Brick Wall Installation Using Conventional Mortar

Table 4. Observation Results of Installing Bricks With Conventional Mortar Materials Using the Daily Record Sheet Method

\begin{tabular}{ccccccc}
\hline Activity & Day & $\begin{array}{c}\text { Large } \\
\left(\mathrm{m}^{2}\right)\end{array}$ & $\begin{array}{c}\text { Produktivitas } \\
\left(\mathrm{m}^{2} / \mathrm{jam}\right)\end{array}$ & $\begin{array}{c}\text { Time } \\
\left(\mathrm{jam} / \mathrm{m}^{2}\right)\end{array}$ & $\begin{array}{c}\text { The worker } \\
\text { Handyman }\end{array}$ & $\begin{array}{c}\text { Handyman } \\
2\end{array}$ \\
Installation & 1 & 10,00 & 1,25 & 0,1000 & 1 & 1 \\
Brick & 2 & 10,20 & 1,275 & 0,0980 & 1 & 1 \\
Average & 3 & 9,80 & 1,26 & 0,1020 & 1 & 1 \\
\hline
\end{tabular}

(Source: Researcher's Processed Data, 2020)

Table 5. Results of Observation of Plastering Bricks With Conventional Mortar Materials Using the Daily Record Sheet Method

\begin{tabular}{ccccccc}
\multirow{2}{*}{ Activity } & Da & Large & Produktivita & Time & \multicolumn{2}{c}{ The worker } \\
& $\mathrm{y}$ & $\left(\mathrm{m}^{2}\right)$ & $\mathrm{s}$ & $\left(\mathrm{jam} / \mathrm{m}^{2}\right.$ & Handyma & Handyma \\
& 1 & 10,40 & 1,30 & 0,0962 & 1 & $\mathrm{n} 2$ \\
Plastering & 2 & 10,56 & 1,32 & 0,0947 & 1 & 1 \\
& 3 & 10,10 & 1,26 & 0,0990 & 1 & 1 \\
Average & 10,35 & 1,29 & 0,0966 & & \\
\hline
\end{tabular}


(Source: Researcher's Processed Data, 2020)

Pemasangan Dinding Batu Bata Menggunakan Mortar Instan RM-115

Table 6. Observation Results of Installing Bricks With Instant Mortar Material RM-115 Using the Daily Record Sheet Method

\begin{tabular}{ccccccc}
\hline Activity & Day & $\begin{array}{c}\text { Large } \\
\left(\mathrm{m}^{2}\right)\end{array}$ & $\begin{array}{c}\text { Produktivitas } \\
\left(\mathrm{m}^{2} / \mathrm{jam}\right)\end{array}$ & $\begin{array}{c}\text { Time } \\
\left(\mathrm{jam} / \mathrm{m}^{2}\right)\end{array}$ & $\begin{array}{c}\text { The worker } \\
\text { Handyman }\end{array}$ & $\begin{array}{c}\text { Handyman } \\
2\end{array}$ \\
Installation & 1 & 10,53 & 1,32 & 0,0949 & 1 & 1 \\
Brick & 2 & 10,30 & 1,29 & 0,0971 & 1 & 1 \\
Average & 3 & 10,83 & 1,35 & 0,0924 & 1 & 1 \\
\hline
\end{tabular}

(Source: Researcher's Processed Data, 2020)

Table 7. Results of Observation of Plastering Bricks With Instant Mortar Material

RM-115 Using the Daily Record Sheet Method

\begin{tabular}{|c|c|c|c|c|c|c|}
\hline \multirow[b]{2}{*}{ Activity } & \multirow[b]{2}{*}{ Day } & \multirow[b]{2}{*}{$\begin{array}{l}\text { Large } \\
\left(\mathrm{m}^{2}\right)\end{array}$} & \multirow[b]{2}{*}{$\begin{array}{l}\text { Produktivitas } \\
\left(\mathrm{m}^{2} / \mathrm{jam}\right)\end{array}$} & \multirow[b]{2}{*}{$\begin{array}{c}\text { Time } \\
\left(\mathrm{jam} / \mathrm{m}^{2}\right)\end{array}$} & \multicolumn{2}{|c|}{ The worker } \\
\hline & & & & & $\begin{array}{c}\text { Handyman } \\
1\end{array}$ & $\begin{array}{l}\text { Handyman } \\
2\end{array}$ \\
\hline \multirow{3}{*}{ Plesteran } & 1 & 10,70 & 1,34 & 0,09346 & 1 & 1 \\
\hline & 2 & 10,38 & 1,30 & 0,09634 & 1 & 1 \\
\hline & 3 & 11,13 & 1,39 & 0,08989 & 1 & 1 \\
\hline \multicolumn{2}{|l|}{ Average } & 10,74 & 1,34 & 0,09323 & & \\
\hline
\end{tabular}

(Source: Researcher's Processed Data, 2020)

\section{Analysis of Brick Wall Installation Costs}

The calculation of the volume of each job is adjusted to a predetermined working image to obtain results that are close to reality. For residential buildings the work volume calculation is calculated in accordance with the specified dimensions and specifications. The volume is calculated as shown in Figure 4.24 below.
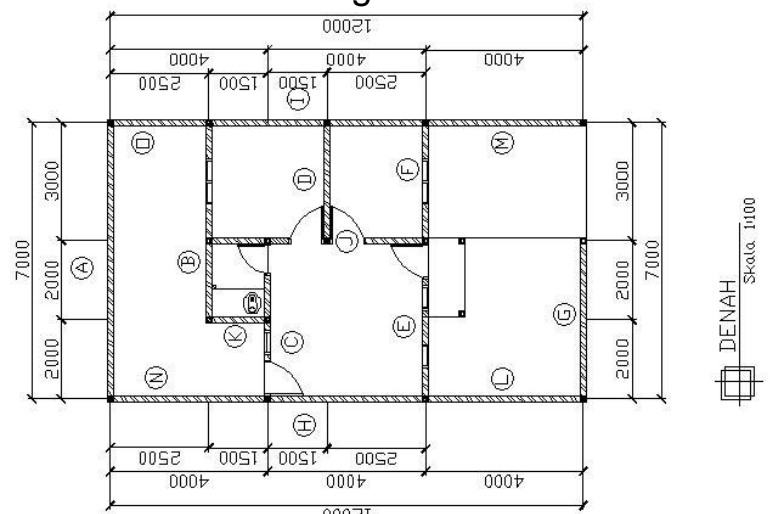

Figure 7. Figure of Plan

(Source: Author, 2020)

The volume of wall pairs obtained from drawings asbuild drawings and shop drawings where the total wall area is calculated using a simple formula length multiplied by the width and subtracted by subtracting components in the wall such as columns, beams, loops, doors, windows etc. The results of the volume calculation are as follows:

- Total Wall Length

$$
\begin{aligned}
\text { High } 3,33 \mathrm{~m}^{2} & =\mathrm{B}+\mathrm{C}+\mathrm{D}+\mathrm{E}+\mathrm{F}+\mathrm{H}+\mathrm{I}+\mathrm{J}+\mathrm{K} \\
\text { High } 1,2 \mathrm{~m}^{2} & =5+4+3+4+3+4+5,5+5,5+1,5=35,5 \mathrm{~m}^{2} \\
& =\mathrm{G}+\mathrm{M}+\mathrm{L} \\
& =4+4+4=12 \mathrm{~m}^{2}
\end{aligned}
$$


High $2,5 \mathrm{~m}^{2} \quad=\mathrm{A}+\mathrm{N}+\mathrm{O}$

Overall Wall Area

$$
=7+4+2,5=13,5 \mathrm{~m}^{2}
$$

\begin{tabular}{|c|c|}
\hline $\begin{array}{l}\text { High } 3,33 \mathrm{~m}^{2} \\
\text { High } 1,2 \mathrm{~m}^{2} \\
\text { High } 2,5 \mathrm{~m}^{2}\end{array}$ & $\begin{array}{l}=3,33 \times 35,5=118,215 \mathrm{~m}^{2} \\
=1,2 \times 12=14,4 \mathrm{~m}^{2} \\
=2,5 \times 13,5=33 \mathrm{~m}^{2}\end{array}$ \\
\hline
\end{tabular}

Total Overall Wall Area $=118,215+14,4+33,75=166,365 \mathrm{~m}^{2}$

Area of Doors and Windows

Living room door, front room door, back room door, kitchen door

Door k. bath

$$
=2,1 \times 0,9 \times 4=7,56 \mathrm{~m}^{2}
$$

Living room window and kitchen window

$$
=2,1 \times 0,8=1,68 \mathrm{~m}^{2}
$$

$$
=1,6 \times 0,6 \times 3=2,88 \mathrm{~m}^{2}
$$

Bedroom window $\quad=1,6 \times 1,115=1,784 \mathrm{~m}^{2}$

Total Area of Doors and Windows $=7,56+1,68+2,88+1,784=13,904 \mathrm{~m}^{2}$

- Overall Wall Volume

Wall volume = Overall wall area - area of window door

$$
=166,365-13,904=152,461 \mathrm{~m}^{2}
$$

Unit prices for materials really need to be known. This is used as a reference for estimating the total building price. Material prices are obtained from survey results on the market which are then collected in a list called a unit price list of materials. The price of materials used is 2020 in Jakarta, according to the project location.

The unit price analysis data is obtained from the calculation itself by the researcher and SNI for wall work. The price is in accordance with the price of materials and labor provisions in the area of PU Prambanan, so for the draft budget the cost is obtained from the price analysis of the unit price multiplied by the volume of the wall pair. Calculation of the amount of costs required for materials and wages, as well as other costs associated with implementing the building or project.

\section{$\mathrm{RAB}=\boldsymbol{\Sigma}$ (Volume) $\mathrm{x}$ Unit Price of Work}

After calculating the material needs, labor and unit price of material / wage, the price for each work of the wall will be obtained.

\section{Price of Brick and Plastering Wall Installation Using Conventional Mortar Materials - Direct Cost}

1. Work on the Installation and Plastering of Brick Wall Using Conventional Mortar Materials as follows: 
:: IJEEIT ::

(International Journal of Electrical Engineering and Information Technology)

This work is licensed under a Creative Commons Attribution- ShareAlike 4.0 International License.

Table 8. Data on Wall Installation Costs Using Conventional Cement

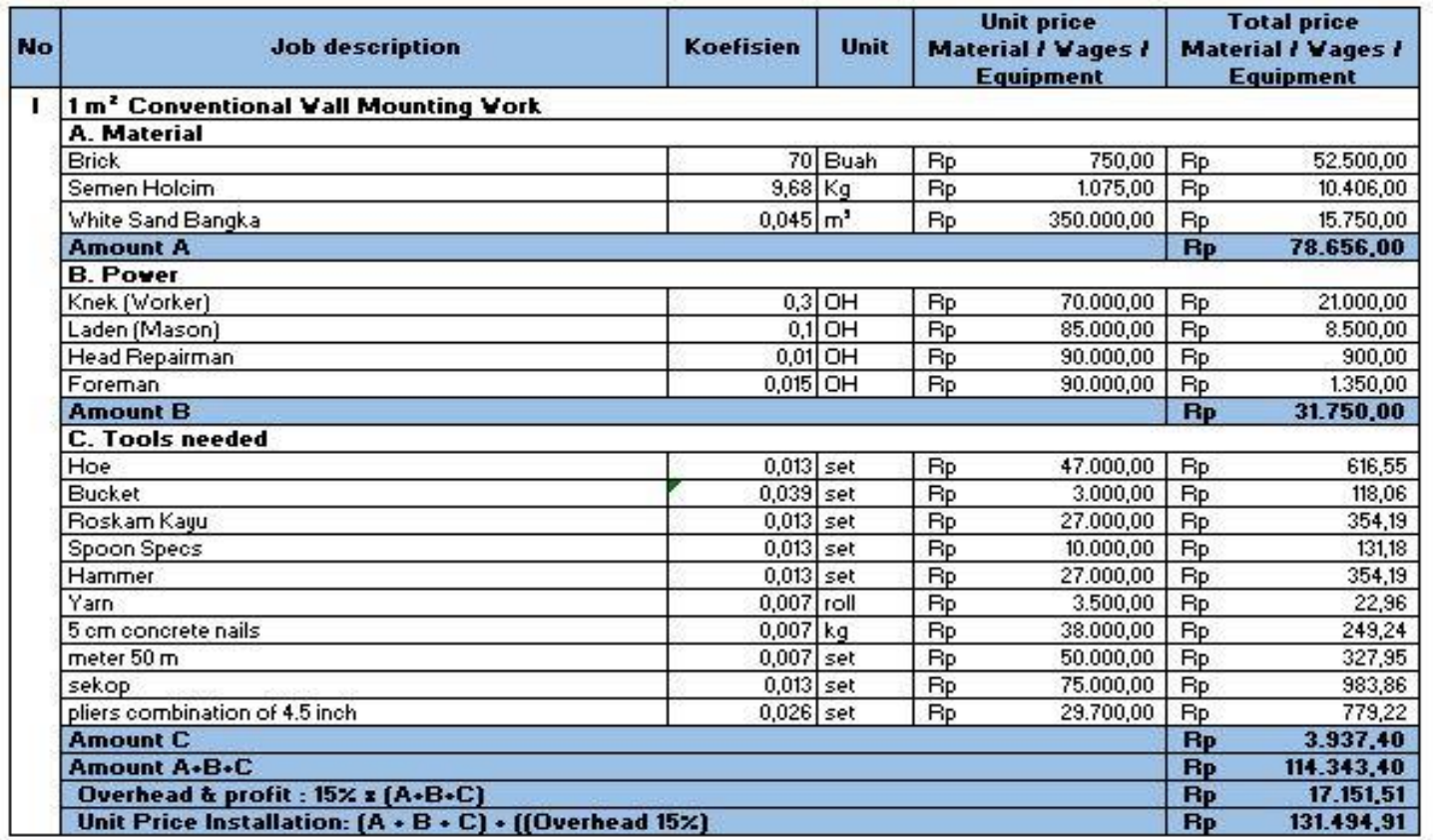

(Source: SNI 2837: 2008, Point 6.5 and SNI 6897: 2008, Point 6.10)

Table 9. Data on Wall Plastering Costs Using Conventional Cement

\begin{tabular}{|c|c|c|c|c|c|c|}
\hline \multirow{3}{*}{\begin{tabular}{l|} 
No \\
II
\end{tabular}} & \multirow{3}{*}{$\begin{array}{l}1 \mathrm{~m}^{2} \text { Plastering York } \\
\text { A. Material }\end{array}$} & \multirow[t]{3}{*}{ Koefisien } & \multirow[t]{3}{*}{ Unit } & $\begin{array}{c}\text { Unit price } \\
\text { Material I Yages I } \\
\text { Equipment }\end{array}$ & \multicolumn{2}{|c|}{$\begin{array}{c}\text { Total price } \\
\text { Material } / \text { Yages / } \\
\text { Equipment }\end{array}$} \\
\hline & & & & & & \\
\hline & & & & \multicolumn{3}{|c|}{ A. Material } \\
\hline & Semen Holcim & 5,184 & $\mathrm{Kg}$ & $1.075,00$ & $\mathrm{Rp}$ & $5.572,80$ \\
\hline & White Sand Bangka & 0,026 & $\mathrm{~m}^{2}$ & $350.000,00$ & Rip & $9.100,00$ \\
\hline & \multicolumn{4}{|l|}{ Amount A } & Rp & 14.672 .80 \\
\hline & \multicolumn{6}{|l|}{ B. Power } \\
\hline & Knek (Worker) & 0,3 & $\mathrm{OH}$ & $70.000,00$ & Rip & $21.000,00$ \\
\hline & Laden (Mason) & 0,15 & $\mathrm{OH}$ & $85.000,00$ & Rip & $12.750,00$ \\
\hline & Head Repairman & 0,015 & $\mathrm{OH}$ & $90.000,00$ & Rip & $1.350,00$ \\
\hline & Foreman & 0,015 & $\mathrm{OH}$ & $90.000,00$ & Rp & $1.350,00$ \\
\hline & \multicolumn{4}{|l|}{$\begin{array}{l}\text { Amount B } \\
\text { C Tools needed }\end{array}$} & Rp & $36.450,00$ \\
\hline \multicolumn{7}{|c|}{ C. Tools needed } \\
\hline & Cangkul & 0,013 & set & $47.000,00$ & Rip & 616,55 \\
\hline & Ember & 0,039 & set & $3.000,00$ & Rip & 118,06 \\
\hline & Roskam Kayu & 0,013 & set & $27.000,00$ & Rip & 354,19 \\
\hline & Sendok Spesi & 0,013 & set & $10.000,00$ & Rip & 131,18 \\
\hline & \begin{tabular}{|l|} 
Palu \\
\end{tabular} & 0,013 & set & $27.000,00$ & Rip & 354,19 \\
\hline & Benang & 0,007 & roll & $3.500,00$ & Rip & 22,96 \\
\hline & Paku beton $5 \mathrm{~cm}$ & 0,007 & $\mathrm{~kg}$ & $38.000,00$ & Fip & 249,24 \\
\hline & Jidar kayu kaso 4 * 6 & 0,026 & $\mathrm{~m}^{2}$ & $28.000,00$ & $\mathrm{Rp}$ & 734,61 \\
\hline & meteran $50 \mathrm{~m}$ & 0,007 & set & $50.000,00$ & $\mathrm{Rip}$ & 327,95 \\
\hline & shovel & 0,013 & set & $75.000,00$ & Rip & 983,86 \\
\hline & pliers combination of 4.5 inch & 0,026 & set & $29.700,00$ & Rip & 779,22 \\
\hline & \multicolumn{4}{|l|}{ Amount C } & Rp & $4.672,01$ \\
\hline & \multicolumn{4}{|l|}{ Amount A*B+C } & $\mathbf{R p}_{\mathrm{p}}$ & 55.794 .81 \\
\hline & \multicolumn{4}{|l|}{ Overhead \& profit : $15 \%=(A+B+C)$} & $\mathbf{R p}_{\mathbf{p}}$ & 8.369 .22 \\
\hline & \multicolumn{4}{|c|}{ Unit Price Plastering: $(A+B+C) \cdot[($ Overhead $15 \%)$} & $\mathbf{R p}$ & 64.164 .04 \\
\hline
\end{tabular}

(Source: SNI 2837: 2008, Point 6.5 and SNI 6897: 2008, Point 6.10)

Unit prices for masonry and plaster work use conventional mortar materials with the sum as follows:

Red brick pair $1 / 2$ brick + Plastering Work

Rp. $131,494.91+$ Rp. $64,164.04$ = Rp. $195,658.95$

For the overall wall volume of $152,461 \mathrm{~m}^{2}$, the cost of carrying out the brickwork is as follows:

Total cost $=$ brick wall installation + plaster work 
$=\left(152,461 \mathrm{~m}^{2} \times\right.$ Rp. $\left.131,494.91\right)+\left(152,461 \mathrm{~m}^{2} \times\right.$ Rp. 64,164.04 $)$

$=$ Rp. $29,830,358.73$

2. Total Time of Brick Wall Work Using Conventional Mortar Materials

Table 9. Calculation of the Total Time of Installation of Project Work Walls Using

Conventional Mortar Materials

\begin{tabular}{ccccc} 
No & Observation Type & $\begin{array}{c}\text { Produktivitas } \\
\left(\mathrm{m}^{2} / 8 \text { jam }\right)\end{array}$ & $\begin{array}{c}\text { Wall Area } \\
\left(\mathrm{m}^{2}\right)\end{array}$ & Days \\
1 & Installing Bricks & 10,000 & 152,461 & 8 \\
2 & Plastering & 10,353 & 152,461 & 7 \\
\hline
\end{tabular}

(Source: Researcher Processed Data, 2020)

From table 4.9 it can be seen that the productivity needed to complete all conventional brick wall work on each type of observation is: installation: $10 / 8=1.26 \mathrm{~m}^{2} /$ hour, and plastering: $10.353 / 8=1.29 \mathrm{~m}^{2} /$ hour. Indrect Cost

Table 10. Work of Plastering and Plastering Walls Using Conventional Mortar Materials

\begin{tabular}{|c|l|c|r|r|r|}
\hline No & \multicolumn{1}{|c|}{ Position } & Amount & \multicolumn{1}{c|}{ Salary } & Duration of Work & Total Biaya \\
\hline 1 & Project Manager & 1 & 22.000 .000 & 16 days & 1.467 .400 \\
\hline 2 & Engineering Team & 1 & 6.000 .000 & 16 days & 400.200 \\
\hline 3 & Supervisor & 1 & 5.500 .000 & 16 days & 366.850 \\
\hline 4 & Commercial & 1 & 7.000 .000 & 16 days & 466.900 \\
\hline 5 & Finance & 1 & 6.000 .000 & 16 days & 400.200 \\
\hline \multicolumn{7}{|c|}{ TOTAL } & 2.701 .350 \\
\hline
\end{tabular}

\begin{tabular}{ccr}
\hline DESKRIPSI & & \multicolumn{1}{c}{ PRICE } \\
\hline Direct Cost & $\mathrm{Rp}$ & $29.830 .358,73$ \\
Indirect Cost & $\mathrm{Rp}$ & 2.701 .350 \\
SPF & $\mathrm{Rp}$ & $975.951,26$ \\
Margin 10\% & $\mathrm{Rp}$ & $3.350 .766,00$ \\
TOTAL & $\mathrm{Rp}$ & $\mathbf{3 6 . 8 5 8 . 4 2 5 , 9 9}$ \\
\hline
\end{tabular}

(Source: Author, 2020)

\section{Price of Plastering and Plastering Walls Using Instant Mortar Materials RM-115}

Direct Cost

1. Work on the Installation of Bricks and Plastering Walls Using Instant Mortar Materials RM- 115 as follows : 
Table 11. Data on Wall Mounting Costs Using Neat Cement RM-115

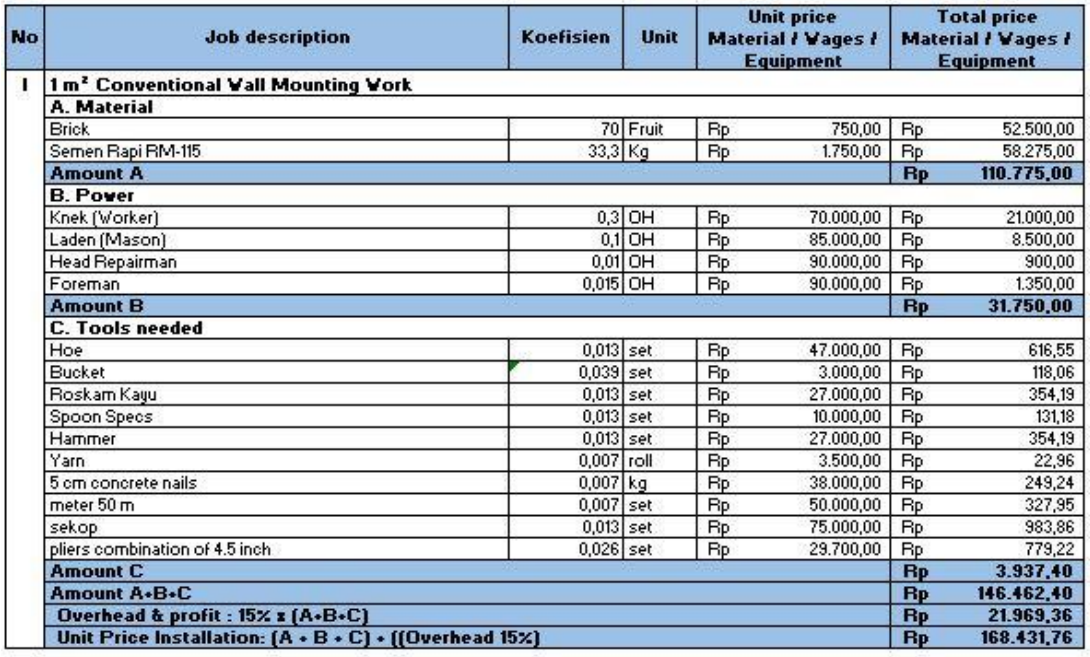

(Source: SNI 2837: 2008, Point 6.5 and SNI 6897: 2008, Point 6.10)

Table 12. Plaster Wall Cost Data Using Cement RM-115

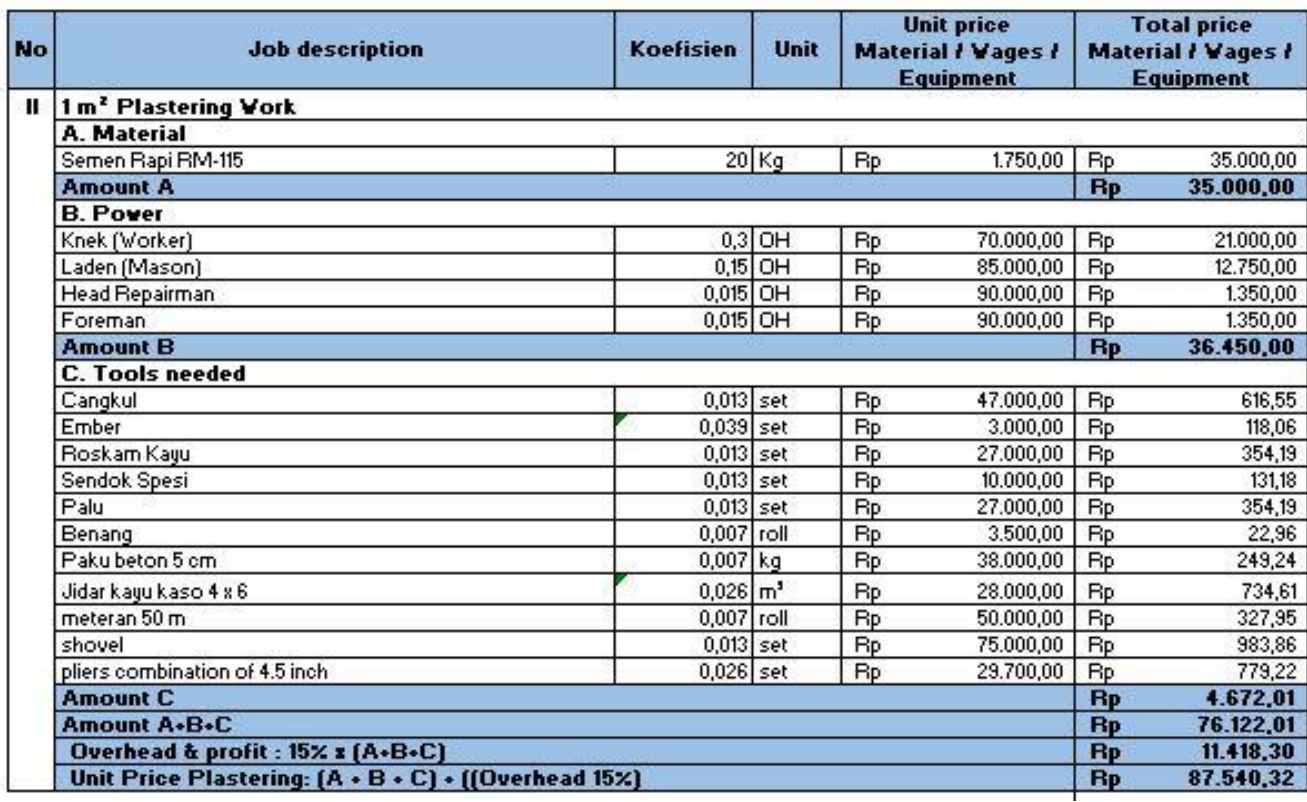

(Source: SNI 2837: 2008, Point 6.5 and SNI 6897: 2008, Point 6.10)

Unit prices for masonry and plaster work using mortar materials RM-115 with the sum as follows:

Red brick pair $1 / 2$ brick + Plastering Work

Rp. $168,431.76+$ Rp. $87,540.32=$ Rp. $255,972.08$

For the overall wall volume of $152,461 \mathrm{~m}^{2}$, the cost of carrying out the brickwork is as follows:

Total cost $\quad=$ brick wall installation + plaster work

$=\left(152,461 \mathrm{~m}^{2} \times\right.$ Rp. $\left.168,431.76\right)+\left(152,461 \mathrm{~m}^{2} \times \mathrm{Rp} .87,540.32\right)$

$=$ Rp. $39,025,758.85$

2. Total time work of batu bata use ingredients Instan Mortar RM-115 
Table 13. Calculation of Total Time of Installation of Project Work Walls Using Instant Mortar Material RM-115

\begin{tabular}{ccccc} 
No & Observation Type & $\begin{array}{c}\text { Produktivitas } \\
\left(\mathrm{m}^{2} / 8 \text { jam }\right)\end{array}$ & $\begin{array}{c}\text { Wall Area } \\
\left(\mathrm{m}^{2}\right)\end{array}$ & Days \\
1 & Installing Bricks & 10,553 & 152,461 & 7 \\
2 & Plastering & 10,735 & 152,461 & 7 \\
\hline
\end{tabular}

(Sumber : Data Olahan Peneliti, 2020)

From table 4.10 it can be seen that the productivity needed to complete all conventional brick wall work on each type of observation is: installation: $10.55 / 8=1.32 \mathrm{~m}^{2} /$ hour, and plastering: $10.74 / 8=1.34 \mathrm{~m}^{2} /$ hour.

- Indrect Cost

Table 14. Brick and Plastering Installation Work Using Mortar Materials RM-115

\begin{tabular}{|c|l|c|r|r|r|}
\hline No & \multicolumn{1}{|c|}{ Position } & Amount & \multicolumn{1}{c|}{ Salary } & Duration of Worl & Total Biaya \\
\hline 1 & Project Manager & 1 & 22.000 .000 & 15 days & 1.467 .400 \\
\hline 2 & Engineering Team & 1 & 6.000 .000 & 15 days & 375.000 \\
\hline 3 & Supervisor & 1 & 5.500 .000 & 15 days & 343.750 \\
\hline 4 & Commercial & 1 & 7.000 .000 & 15 days & 437.500 \\
\hline 5 & Finance & 1 & 6.000 .000 & 15 days & 375.000 \\
\hline \multicolumn{7}{|c|}{ TOTAL } & 2.623 .650 \\
\hline
\end{tabular}

\begin{tabular}{ccc}
\hline DESKRIPSI & & PRICE \\
\hline Direct Cost & $\mathrm{Rp}$ & $39.025 .758,85$ \\
Indirect Cost & $\mathrm{Rp}$ & 2.623 .650 \\
SPF & $\mathrm{Rp}$ & $1.249 .482,27$ \\
Margin 10\% & $\mathrm{Rp}$ & $4.289 .889,11$ \\
TOTAL & $\mathrm{Rp}$ & $\mathbf{4 7 . 1 8 8 . 7 8 0 , 2 2}$ \\
\hline
\end{tabular}

(Sumber: Data Olahan Peneliti, 2020)

3. Analysis Results of a Comparison of Quality, Cost, and Time of Conventional Mortar and Instant Mortar

Table 15. Comparison of Quality of Cost and Time of Wall Installation Using Mortar Materials

\begin{tabular}{|c|c|c|c|}
\hline No. & Deskripsi & Conventional Mortar & Instant Mortar RM-115 \\
\hline 1 & Quality & 151,76 & 215,88 \\
\hline 2 & Cost & $36.858 .425,99$ & 47.188.780,22 \\
\hline 3 & Day & 15 & 14 \\
\hline
\end{tabular}

(Source: Researcher Processed Data, 202

\section{CONCLUSIONS AND RECOMMENDATIONS}

1. Based on the analysis, conclusions can be drawn regarding compressive strength, productivity and cost of installing red brick walls and comparison plastering using Conventional Mortar materials with neat Instant Mortar RM-115.

2. Compressive strength testing in 28 days the compressive strength of Instant Mortar RM-115 has a compressive strength value of $215.88 \mathrm{~kg} / \mathrm{cm} 2$ which is 
larger and more measurable compared to Conventional Mortar which has a value of $151.76 \mathrm{~kg} / \mathrm{cm} 2$ whose implementation is sometimes less precise, Instant Mortar is more durable than Conventional Mortar.

2. The time needed to complete the work of red brick wall plaster and stucco using RM115 Instant Mortar material is 14 days, while the time required for the work of red brick wall plaster and plastering using Conventional Mortar material is 15 days. So that the work of red brick and plastering wall pairs using Instant Mortar materials RM-115 is more efficient 1 day and cleaner storage compared to using conventional Mortar materials.

3. The price of installing red brick walls and stucco using RM-115 Mortar materials in Bintaro Sector 7 housing is Rp. 36,858,425.99. While the price of installing red brick walls and plaster using conventional Mortar materials in Bintaro Sector 7 housing is Rp. 47,188,780.22. Work Installation of red brick walls and plaster using Mortar materials RM-115 is more expensive with a difference of Rp. 10,330,354.23.

\section{REFERENCES}

Abubakar, Yuliandi, et al. "Model Koefisien Produktivitas Pekerjaan Pemasangan Bata Ringan Pada Perumahan Sederhana." Prosiding Semnastek (2017).

Al-Baijat, Hamadallah. "Dynamic Modulus of Elasticity of Some Mortars Prepared from Selected Jordanian Masonry Cements." Open Journal of Composite Materials 9.2 (2019): 199-206.

ASTM International ( An American National Standard). 2002. ASTM - C270 - 07 Standard Specification for Mortar for Unit Masonry. West Conshohoken, PA 19428 - 2959, United States.

Barron, Akhmad. "Pengaruh Komposisi Campuran Mortar Terhadap Kuat Tekan Dinding Pasangan Bata Merah Dengan Plesteran." Sinteks: Jurnal Teknik 1, no. 1 (2012).

Firdaus, Iqbal Adie Surya. "Perbandingan Estimasi Biaya Pekerjaan Dinding Bata Merah, Bata Ringan, Batako dan M Panel (Studi Kasus: SATLANTAS POLRES Sleman)." (2019).

Kartadipura, Retna Hapsari. "Analisa Strategi Pemilihan Material Pasangan Dinding." INFO-TEKNIK 14.2 (2016): 158-170.

Lasino, L. and Rachman, D., 2012. Kajian Penggunaan Produk Mortar Siap Pakai (MSP) Pada Industri Kontruksi. Jurnal Teknologi Bahan dan Barang Teknik, 2(1), pp.1524.

Leroy, Mambou Ngueyep Luc, et al. "Density and Strength of Mortar Made with the Mixture of Wood Ash, Crushed Gneiss and River Sand as Fine Aggregate." Journal of Materials Science and Chemical Engineering 6.4 (2018): 109-120.

Negara, Kartika Puspa, et al. "Perhitungan Harga Satuan Pekerjaan Dinding Bata Ringan Dengan Metode SNI Dan Ms. Project Pada Proyek Pembangunan Gedung Laboratorium Enterpreneurship Terpadu Universitas Brawijaya Malang." Rekayasa Sipil 9.2 (2015): 159-167.

Pascanawaty, Maya Saridewi, M. Sukrawa, and IA M. Budiwati. "Studi Eksperimental Tentang Kekuatan Dinding Bata dengan Perkuatan." JURNAL SPEKTRAN 4.1 (2016).

Prapto, Pusoko, and Bada Haryadi. "Studi Perbandingan Biaya Per $1 \mathrm{~m} 2$ Pekerjaan Pasangan Dinding Bata Ringan Dengan Pasangan Bata Merah." INformasi dan Ekspose hasil Riset Teknik SIpil dan Arsitektur 13.1 (2017): 27-40.

Purwanti, H., 2017. Analisis Perbandingan Waktu dan Biaya dalam Penggunaan Bata Merah dengan M-Panel. Jurnal Teknologi| Jurnal Pakuan Bidang Keteknikan, 2(24). 
PY, Rifky Rezha, and Saifoe El Unas. "Analisa Produktivitas Pekerjaan Dinding Panel, Dinding Batu Bata Konvensional, Dan Sni Pekerjaan Dinding." Jurnal Mahasiswa Jurusan Teknik Sipil 1.2 (2015): pp-243.

Sari, Sely Novita. "Evaluasi Anggaran Biaya menggunakan Batu Bata Merah dan Batu Bata Ringan Gedung Kantor Kelurahan Bareng Kecamatan Klaten Tengah Kabupaten Klaten." Jurnal Qua Teknika 9.1 (2019): 1-10.

SNI. 03-6825-2002, Metode Pengujian Kekuatan Tekan Mortar Semen Portland Untuk Pekerjaan Sipil.

SNI. 03-6882-2002, Spesifikasi Mortar Untuk Pekerjaan Pasangan, Badan Standar Nasional, Jakarta. Jakarta: BSNI.

SNI 2837.2008. Tata Cara Perhitungan Harga Satian Pekerjaan Plesteran untuk Bangunan Gedung dan Perumahan. Jakarta: BSNI.

SNI 6897.2008. Tata Cara Perhitungan Harga Satian Pekerjaan Dinding untuk Bangunan Gedung dan Perumahan. Jakarta: BSNI.

Trijeti, Trijeti, Sevina Yasti Putri, and Andika Setiawan. "Perbandingan Dinding Prefab Cement Wall Dengan Bata Konvensional Pada Bangunan Rumah." Prosiding Semnastek (2017).

Umum, Kementrian Pekerjaan. Peraturan Menteri Pekerjaan Umum dan Perumahan Rakyat Nomor 02. PRT/M/2016 Tentang Pedoman Analisis Harga Satuan Pekerjaan Bidang Pekerjaan Umum, Kementrian Pekerjaan Umum Dan Perumahan Rakyat, Jakarta, 2016.

Wenno, Rudolvo, Steenie E. Wallah, and Ronny Pandaleke. "Kuat Tekan Mortar Dengan Menggunakan Abu Terbang (Fly Ash) Asal PLTU Amurang Sebagai Substitusi Parsial Semen." Jurnal Sipil Statik 2, no. 5 (2014).

Zuraidah, Safrin, and Budi Hastono. "Pengaruh Variasi Komposisi Campuran Mortar Terhadap Kuat Tekan." Ge-STRAM: Jurnal Perencanaan dan Rekayasa Sipil 1.1 (2018): 8-13. 